\title{
Method Validation of Contact and Immersion TLC- bioautography for Determination of Streptomycin Sulfate in Shrimp
}

\author{
Karideste Streptomisin Sülfat Tayini için Kontak ve İmmersiyon ITK- \\ biyootografi Yönteminin Validasyonu
}

\author{
(D) Febri ANNURYANTI, (D) Isnaeni ISNAENI*, (D) Asri DARMAWATI, (D) Iftitahatur ROSYIDAH, (D) Aprelita Nurelli DWIANA \\ Airlangga University, Department of Pharmaceutical Chemistry, Surabaya, Indonesia
}

\begin{abstract}
Objectives: Contact and immersion thin layer chromatography (TLC)-bioautography were developed for identification and quantification of streptomycin sulfate in shrimp.

Materials and Methods: TLC of streptomycin sulfate standard solution was carried out using silica gel $\mathrm{F}_{254}$ and $7.5 \%$ of $\mathrm{KH}_{2} \mathrm{PO}_{4}$ solution as stationary and mobile phase, respectively.

Results: The retardation factor of the streptomycin sulfate standard was 0.51 and the selectivity of streptomycin sulfate was 4.1 with the presence of kanamycin sulfate in the shrimp. The bioautography was performed with Escherichia coli ATCC 8739 as a test bacterium. The limit of detection of streptomycin sulfate obtained by contact and immersion TLC-bioautography was $0.24 \mu \mathrm{g}$ and $0.16 \mu \mathrm{g}$, respectively. Both methods showed good linearity with an $r$ value greater than 0.999 and a $V x$ xo value less than $2 \%$. The accuracy of the contact and immersion TLC-bioautography was tested by standard addition method and the obtained percentage recovery was $86.93 \pm 1.60 \%$ and $96.42 \pm 0.65 \%$, respectively. The coefficient of variation of the contact and immersion TLC-bioautography was $2.39 \pm 1.79 \%$ and $0.53 \pm 0.17 \%$, respectively.

Conclusion: The immersion TLC-bioautography was more sensitive with better recovery than the contact TLC-bioautography. In addition, immersion TLC-bioautography was successfully employed for determination of streptomycin sulfate in shrimp.
\end{abstract}

Key words: Streptomycin sulfate, contact TLC-bioautography, immersion TLC- bioautography, shrimp

Öz

Amaç: Kontak ve immersiyon ince tabaka kromatografisi (ITK)-biyootografi, karideslerde streptomisin sülfatın tanımlanması ve miktarının belirlenmesi için geliştirilmiştir.

Gereç ve Yöntemler: ITK, streptomisin sülfat standart çözeltisi, sabit ve hareketli faz olarak sırasıyla silika jel $\mathrm{F}_{254}$ ve $\% 7,5 \mathrm{KH}_{2} \mathrm{PO}_{4}$ çözeltisi kullanılarak gerçekleştirilmiştir.

Bulgular: Streptomisin sülfat standardının alıkonma zamanı 0,51 olarak bulunmuștur ve karideste kanamisin sülfat varlığında streptomisin sülfatın seçiciliği 4,1 olarak tespit edilmiştir. Biyootografi, bir test bakterisi olan Escherichia coli ATCC 8739 kullanılarak yapılmıştır. Kontak ve immersiyon ITK-biyootografi ile elde edilen streptomisin sülfat tayini için sınır değerler, sırasıyla 0,24 $\mu$ g ve 0,16 $\mu$ g olarak bulunmuştur. Her iki yöntem de $r$ değeri 0,999'dan büyük ve Vxo değeri \%2'den düșük olan iyi doğrusallık göstermiștir. Kontak ve immersiyon ITK-biyootografinin doğruluğu standart ekleme yöntemi ile test edildi ve elde edilen yüzde geri kazanım sırasıyla \%86,93 1,60 ve $\% 96,42 \pm 0,65$ olarak bulunmuştur. Kontak ve immersiyon ITK-biyootografinin varyasyon katsayısı sırasıyla $\% 2,39 \pm 1,79$ ve $\% 0,53 \pm 0,17$ 'dir.

Sonuç: İmmersiyon ITK-biyootografi, geri kazanımının daha iyi olması nedeniyle kontak ITK -biyootografiden daha hassas olduğu sonucuna varılmıştır. Ek olarak, immersiyon ITK-biyootografi, karideslerde streptomisin sülfatın belirlenmesi için başarıyla kullanılmıştır.

Anahtar kelimeler: Streptomisin sülfat, kontak ITK-biyootografi, immersiyon ITK-biyootografi, karides

*Correspondence: E-mail: isna.yudi@gmail.com, Phone: +6281331021303 ORCID-ID: orcid.org/0000-0003-4502-2433

Received: 30.01.2019, Accepted: 21.03.2019

๑Turk J Pharm Sci, Published by Galenos Publishing House. 


\section{INTRODUCTION}

Shrimp is one of Indonesia's export commodities with a significant impact on its economy. High export demand sometimes results in uncontrolled cultivation because farmers generally use antibiotics to prevent fish diseases. ${ }^{12}$ As regulated by the Minister of Maritime Affairs and Fisheries in the PER regulation number $02 / \mathrm{MEN} / 2007,{ }^{3}$ fishery products must be free from drug residues, chemicals, biological materials, and other contaminants. One of the antibiotics used by farmers for disease prevention is streptomycin. Streptomycin is an aminoglycoside used for treatment of infections caused by aerobic gram-negative bacteria and is also effective against gram-positive bacteria such as Staphylococcus aureus. ${ }^{4}$ In Indonesia, streptomycin is usually used for treating bacterial diseases in shrimp and ornamental fish. ${ }^{5}$ According to the Codex Alimentarius, the maximum residue limit for streptomycin is 600 $\mu \mathrm{g} / \mathrm{kg} .{ }^{6}$ Antibiotic residues in food can be a risk to human health because they can contribute to antibiotic resistance through the food chain. ${ }^{7}$ Therefore, a fast and perfect analysis method is needed to detect antibiotic residues, especially streptomycin sulfate in shrimp.

Thin layer chromatography (TLC)-bioautography is used for determination of the level of antibiotics in complex samples based on microbiological activities. In TLC-bioautography, determination of antimicrobial levels is initiated by applying antimicrobial analytes to the TLC plate followed by elution with a suitable mobile phase. Contact TLC-bioautography was performed by putting the TLC chromatogram plate on the surface of the agar medium inoculated with the test bacterium and it was left in contact with the agar medium for a certain time for the diffusion process. ${ }^{8}$ Subsequently, the chromatogram plate was removed and incubated for $16-24 \mathrm{~h}$ for the growth range, but this can be reduced to $5-6 \mathrm{~h}$ by spraying 2,6-dichlorophenolindofenol or 2,3,5-tetrazoliumchloride on the surface of the test medium. The antimicrobial activity was determined from the inhibitory zone around the reservoir hole on the surface agar medium or the spot position on the TLC-bioautogram plate, corresponding to the spots on the TLC chromatogram plate. ${ }^{9}$

Immersion bioautography is a combination of direct and contact bioautography. The chromatograms are sprayed until the plate is covered by test medium containing the test bacterium at a temperature of $45^{\circ} \mathrm{C}$. The plate is then cooled to condense and allow the diffusion process. Furthermore, the plate is incubated at a certain temperature for a certain time, and then sprayed with tetrazolium salt to visualize the inhibitory zone.

Antibiotic analysis in the shrimp matrix of kanamycin, ${ }^{10}$ oxytetracycline," and streptomycin sulfate ${ }^{12}$ with the TLCbioautography contact method has been reported. However, comparison of contact and immersion TLC-bioautography methods in determining the levels of streptomycin in frozen shrimp has never been reported, and so it is necessary to conduct research to select a more effective method and provide results that meet the validation parameters.

\section{MATERIALS AND METHODS}

\section{Chemicals}

Streptomycin sulfate and kanamycin sulfate obtained from PT Meiji, shrimp obtained from a local market, Escherichia coli ATCC 8739, $\mathrm{KH}_{2} \mathrm{PO}_{4}$, nutrient broth and nutrient agar (Oxoid), sodium chloride p.a., methanol p.a., TLC silica gel plate $\mathrm{GF}_{254}$ (Merck), methyl thiazole tetrazolium (Sigma Aldrich), distilled water (Otsuka), a microliter syringe (Hamilton), a chromatographic vessel $\left(10 \times 10 \times 6 \mathrm{~cm}^{3}\right)$, an incubator (Memmert), calipers (Tricle brand), an autoclave (Huxley HV340 Speedy), a spectrophotometer (Genesis 20), and a shaker incubator (Thermo Fisher Scientific) were used in this study. Ethic committee approval and patient informed consent were not required.

\section{Preparation of growth medium}

Eighteen grams of agar, $8 \mathrm{~g}$ of nutrient broth powder, and 1000 $\mathrm{mL}$ of distilled water were mixed and heated until dissolved and homogeneous. The liquid medium was poured into a test tube $(10,15$, and $20 \mathrm{~mL})$ and then covered with cotton. The medium was sterilized by autoclaving at $121^{\circ} \mathrm{C}$ for $15 \mathrm{~min} .^{13}$

\section{Preparation of bacterial test}

Escherichia coli ATCC 8739 was inoculated on agar slant medium and incubated at $35-37{ }^{\circ} \mathrm{C}$ for $24-48 \mathrm{~h}$. The bacterial suspension was prepared by adding $10 \mathrm{~mL}$ of sterile saline ( $\mathrm{NaCl} 0.9 \%$ ) solution to a $24 \mathrm{~h}$ culture and shaking by vortex until the entire colony was removed from the surface of the agar medium. A $25 \%$ transmittance of bacteria was measured by spectrophotometer at a wavelength of $580 \mathrm{~nm}$.

\section{Loss on drying of shrimp samples}

Loss on drying was determined according to Indonesian Pharmacope $5^{\text {th }}$ edition..$^{14}$ Sample containers were heated at $105^{\circ} \mathrm{C}$ for $30 \mathrm{~min}$. The container was weighed until it reached constant weight. One gram of each sample was weighed carefully and put into the constant container. The samples were then put in an oven with an open lid. Samples and the lid were heated at $105{ }^{\circ} \mathrm{C}$ until constant weight was obtained. Loss on drying was calculated using the equation below:

Loss on drying=(initial sample weight-final sample weight)/ initial sample weight $\times 100 \%$

Validation method of contact and immersion TLC-bioautography The methods of analysis were validated for the parameters of selectivity, limit of detection, linearity, accuracy, and precision. The accuracy was determined using the standard addition method.

\section{Analysis using contact TLC-bioautography}

First, $8 \mu \mathrm{L}$ of test solution was applied to the silica gel TLC plate $\mathrm{F}_{254}$ and then it was eluted with $7.5 \% \mathrm{KH}_{2} \mathrm{PO}_{4}$ solution as the mobile phase. Subsequently, the TLC plate was dried and attached to the surface of agar inoculated with Escherichia coli in a sterile petri dish. The TLC plate was then stored in the fridge for $1 \mathrm{~h}$ to allow the diffusion and stain process of the compound to the medium. Marks were made on the side of the 
plate followed by incubation of the TLC plate at $37{ }^{\circ} \mathrm{C}$ for $24 \mathrm{~h}$. Finally, the inhibitory zone was observed and its diameter was measured.

\section{Analysis using immersion TLC-bioautography}

First, $8 \mu \mathrm{L}$ of test solution was applied to the silica gel TLC plate $\mathrm{F}_{254}$ and then it was eluted with $7.5 \% \mathrm{KH}_{2} \mathrm{PO}_{4}$ solution as the mobile phase, followed by drying of the TLC plate and it was coated with $15 \mathrm{~mL}$ of inoculated Escherichia coli medium until a thin layer was formed. The TLC plate was stored in a sterile petri dish and then incubated at $37{ }^{\circ} \mathrm{C}$ for $16-18 \mathrm{~h}$. The plates were sprayed with methyl thiazoletetrazolium $(2.5 \mathrm{mg} / \mathrm{mL})$ and finally a white-yellow inhibitory zone was observed..$^{15}$

\section{Statistical analysis}

The analytical characteristics of the TLC-bioautography were validated to ensure conformity to the analytical requirements and the reliability of the results.

All the data analysis was carried out in triplicate and standard deviation and coefficient variation values were calculated.

\section{RESULTS AND DISCUSSION}

The mobile phase, $7.5 \% \mathrm{KH}_{2} \mathrm{PO}_{4}$ solution, used to eluate streptomycin sulfate was based on previous research. ${ }^{13}$ The (retardation factor) Rf results of the contact TLC-bioautography of streptomycin are presented in Table 1. The Rf values met the requirement range of $0.2-0.8$. The loss on drying of the shrimp was $9.44 \pm 1.85 \%$ (Table 2).

The selectivity was tested by spotting of streptomycin sulfate, kanamycin sulfate standard solution, and shrimp on the $F_{254}$ silica gel TLC plate. The elution was carried out by $7.5 \%$ $\mathrm{KH}_{2} \mathrm{PO}_{4}$ solution. The selectivity test results of the contact TLC-

\begin{tabular}{lll}
$\begin{array}{l}\text { Table 1. Retardation factor of streptomycin sulfate standard } \\
\text { analyzed by contact TLC-bioautography }\end{array}$ & \multicolumn{1}{l}{$\begin{array}{l}\text { Concentration of streptomycin } \\
\text { sulfate }(\mathrm{mg} / \mathrm{L})\end{array}$} \\
\hline $7.5 \% \mathrm{KH}_{2} \mathrm{PO}_{4}$ solution & 50.75 & 0.53 \\
\hline 101.50 & 0.51 \\
\hline 152.25 & 0.50 \\
\hline 203.00 & 0.50 \\
\hline 253.75 & 0.53 \\
\hline Mean of $\mathrm{Rf}$ & & 0.51 \\
\hline
\end{tabular}

Rf: Retardation factor, TLC: Thin layer chromatography

\section{Table 2. Loss on drying of shrimp}

\begin{tabular}{llllll}
$\begin{array}{l}\text { Sample } \\
\text { name }\end{array}$ & Replicate & $\begin{array}{l}\text { Initial } \\
\text { weight }(\mathrm{g})\end{array}$ & $\begin{array}{l}\text { Final } \\
\text { weight }(\mathrm{g})\end{array}$ & LOD (\%) & $\begin{array}{l}\text { Mean of } \\
\text { LOD (\%) }\end{array}$ \\
\hline \multirow{2}{*}{ Shrimp } & 1 & 1.0134 & 0.9187 & 9.34 & \multirow{2}{*}{$9.44 \pm 1.85$} \\
\cline { 2 - 5 } & 2 & 1.0187 & 0.9204 & 9.65 & \\
\cline { 2 - 5 } & 3 & 1.0172 & 0.9240 & 9.32 & \\
\hline
\end{tabular}

LOD: Loss on drying bioautography method are depicted in Figure 1 and Table 3. The data showed the $R f$ and resolution (Rs) values of streptomycin and kanamycin sulfate analyzed simultaneously using the contact TLC-bioautography method. The Rs value was 4.1 (Rs $\geq 1.5$ ), which means that both analytes can separate well.

The detection limit was determined by the antibiotic concentration in which activity was still seen. The minimum inhibitory concentration (MIC) of streptomycin sulfate analyzed using contact TLC-bioautography was $30.4 \mathrm{mg} / \mathrm{L}$ with $8 \mu \mathrm{L}$ of sample solution (equivalent to $0.24 \mu \mathrm{g}$ of streptomycin), whereas the MIC of the streptomycin analyzed by immersion TLC-bioautography was $20.3 \mathrm{mg} / \mathrm{L}$ (equivalent to $0.16 \mu \mathrm{gg}$ of streptomycin) (Table 4).

The linearity test of streptomycin in contact and immersion TLC-bioautography was carried out in the concentration range $100-250 \mathrm{mg} / \mathrm{L}$. The linearity of the streptomycin analyzed using contact and immersion TLC-bioautography was $y=14.7212 x-23.2398$ ( $r$ value $=0.9992)$ and $y=12.6655 x-18.5557$ ( $r$ value=0.9994), respectively (Figures 2 and 3 ).

Accuracy and precision were tested by spotting three different concentrations of streptomycin sulfate. The accuracy and

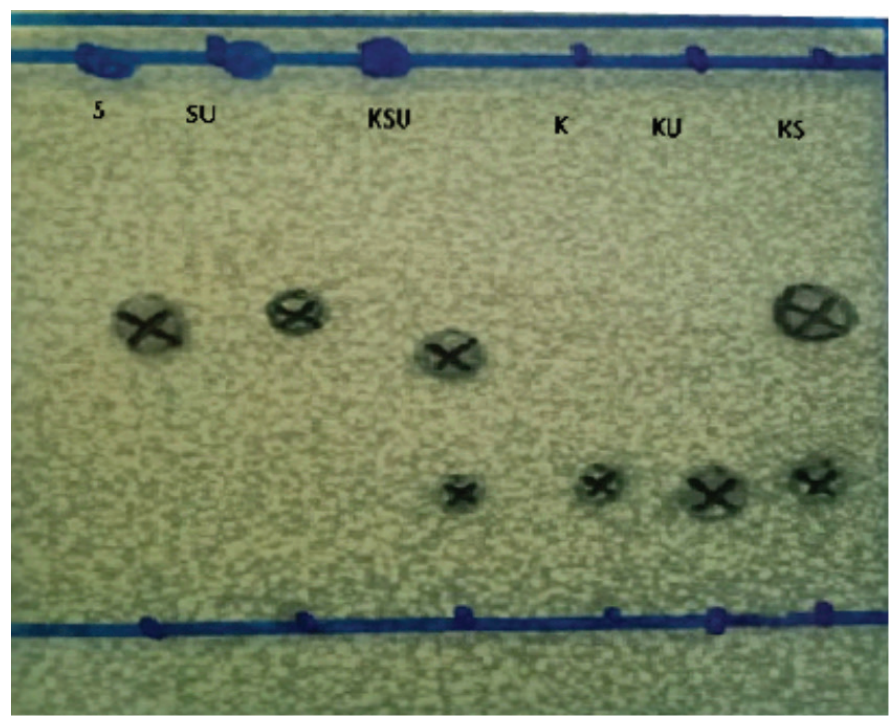

Figure 1. The retardation factor (Rf) of streptomycin sulfate $(\mathrm{S})$ and kanamycin sulfate $(K)$ in shrimp $(U)$ for the determination of resolution (Rs) value

\begin{tabular}{llll}
$\begin{array}{l}\text { Table 3. Resolution value of streptomycin (s), kanamycin (k), and } \\
\text { shrimp (u) }\end{array}$ & Rf (S) & Rf (K) & Rs \\
\hline Compound name & 0.51 & - & - \\
\hline Streptomycin sulfate & 0.52 & - & - \\
\hline Streptomycin + shrimp & 0.50 & 0.21 & 4.1 \\
\hline Kanamycin + streptomycin + shrimp (K+S+U) & - & 0.24 & - \\
\hline Kanamycin & - & 0.22 & - \\
\hline Kanamycin + shrimp & 0.52 & 0.24 & 3.9 \\
\hline Kanamycin + streptomycin & & &
\end{tabular}

Rs: Resolution, Rf: Retardation factor, S: Streptomycin sulfate, K: Kanamycin 
Table 4. Detection limit of streptomycin analyzed using contact and immersion TLC-bioautography method

\begin{tabular}{|c|c|c|c|}
\hline $\begin{array}{l}\text { Method of TLC- } \\
\text { bioautography }\end{array}$ & $\begin{array}{l}\text { Concentration } \\
\text { (mg/L) }\end{array}$ & Inhibitory zone & $\begin{array}{l}\text { Diameter of } \\
\text { inhibitory zone } \\
(\mathrm{mm})\end{array}$ \\
\hline \multirow[t]{5}{*}{ Contact } & 20.3 & - & - \\
\hline & $30.4^{(a)}$ & + & 4.90 \\
\hline & 40.6 & + & 6.10 \\
\hline & 50.8 & + & 6.70 \\
\hline & 60.9 & + & 8.10 \\
\hline \multirow[t]{5}{*}{ Immersion } & 5.1 & - & - \\
\hline & 10.2 & - & - \\
\hline & 15.2 & - & - \\
\hline & $20.3^{(b)}$ & + & 3.50 \\
\hline & 30.4 & + & 4.60 \\
\hline
\end{tabular}

(a): Detection limit of streptomycin sulfate in contact TLC-bioautography, ${ }^{(b)}$ : detection limit of streptomycin sulfate in immersion TLC-bioautography, TLC: Thin layer chromatography

precision results of streptomycin sulfate analyzed by the two methods of TLC-bioautography are shown in Tables 5 and 6 , respectively.

The contact and immersion TLC-bioautography methods developed for the determination of streptomycin sulfate and kanamycin sulfate were precise and reliable by only using a single, cheap, and hazardless solvent. Based on the TLCbioautogram, the regression linear equation is capable of reliably predicting analyte concentration in the range of $5-100 \mathrm{mg} / \mathrm{mL}$ and $0.1-100 \mathrm{mg} / \mathrm{mL}$ for streptomycin sulfate and kanamycin sulfate, respectively.

\section{CONCLUSION}

The method was validated successfully and can be used to simultaneously determine streptomycin sulfate and kanamycin sulfate in a common market frozen shrimp. Those simple methods are recommended for monitoring antibiotic abuse in frozen foods, especially for streptomycin at the concentration of $0.16 \mu \mathrm{g}$ in the presence of kanamycin sulfate.

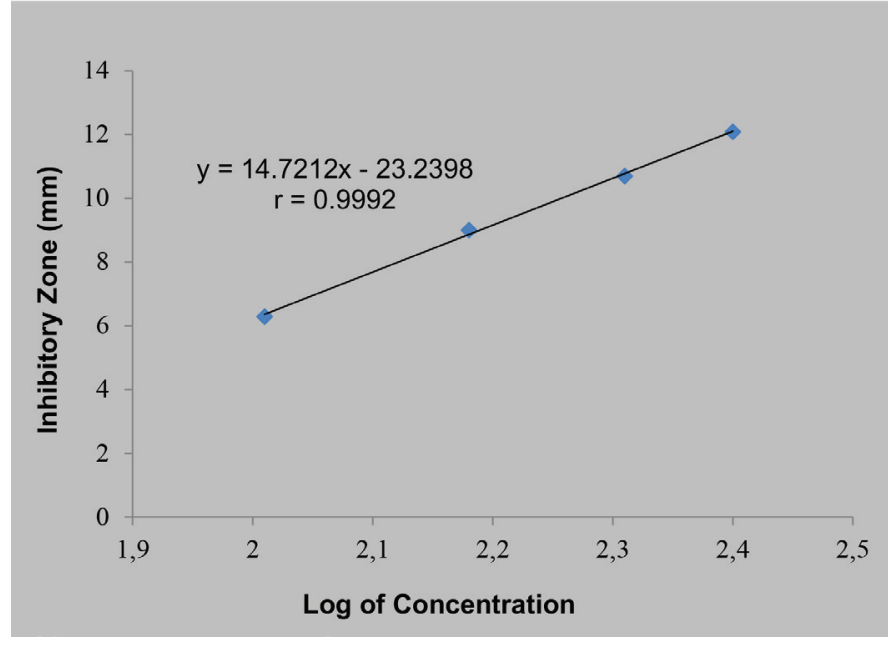

Figure 2. Linear regression of streptomycin sulfate analyzed using contact TLC-bioautography

TLC: Thin layer chromatography

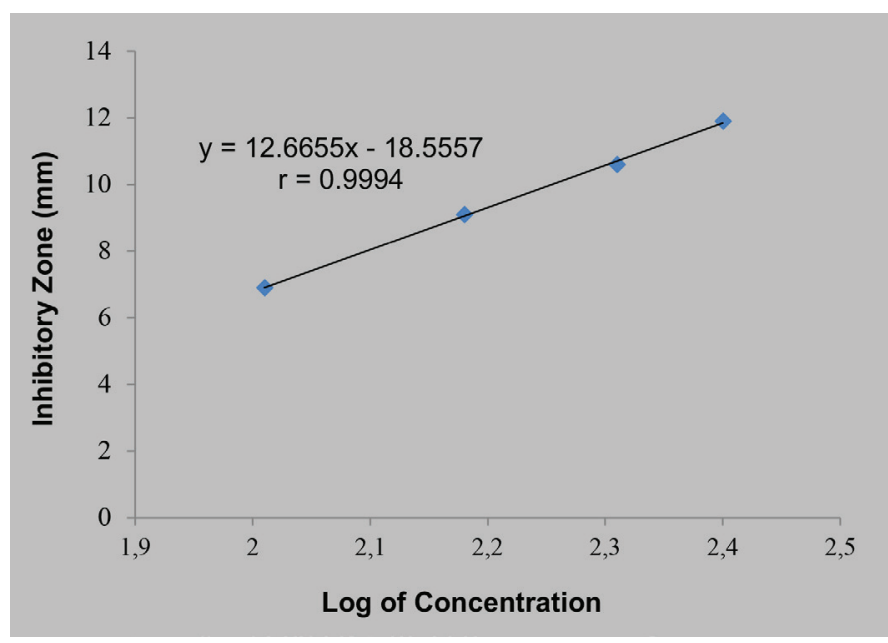

Figure 3. Linear regression of streptomycin sulfate analyzed using immersion TLC-bioautography

TLC: Thin layer chromatography

Table 5. Accuracy of streptomycin sulfate analyzed by contact and immersion TLC-bioautography

\begin{tabular}{lllllll} 
Method & Replicate & Added amount $(\mu \mathrm{g})$ & $\begin{array}{l}\text { Inhibitory zone } \\
(\mathrm{mm})\end{array}$ & $\begin{array}{l}\text { Obtained amount } \\
(\mu \mathrm{g})\end{array}$ & $\begin{array}{l}\text { \% } \\
\text { Recovery }\end{array}$ & $\begin{array}{l}\text { Mean of \% recovery } \\
( \pm \text { SD) }\end{array}$ \\
\hline Contact TLC-bioautography & $\mathrm{I}$ & 1.2992 & 8.50 & 1.1459 & 88.20 & $86.93 \pm 1.60$ \\
\cline { 2 - 6 } & II & 1.4616 & 9.20 & 1.2785 & 87.47 \\
\cline { 2 - 6 } & III & 1.6240 & 9.70 & 1.3825 & 85.13 \\
\hline $\begin{array}{l}\text { Immersion TLC- } \\
\text { Bioautography }\end{array}$ & I & 1.2992 & 9.20 & 1.2432 & 95.69 & $96.42 \pm 0.65$ \\
\cline { 2 - 6 } & II & 1.4616 & 9.90 & 1.4119 & 96.60 \\
\hline
\end{tabular}

SD: Standard deviation, TLC: Thin layer chromatography 
Table 6. Precision of streptomycin sulfate analyzed by contact and immersion TLC-bioautography

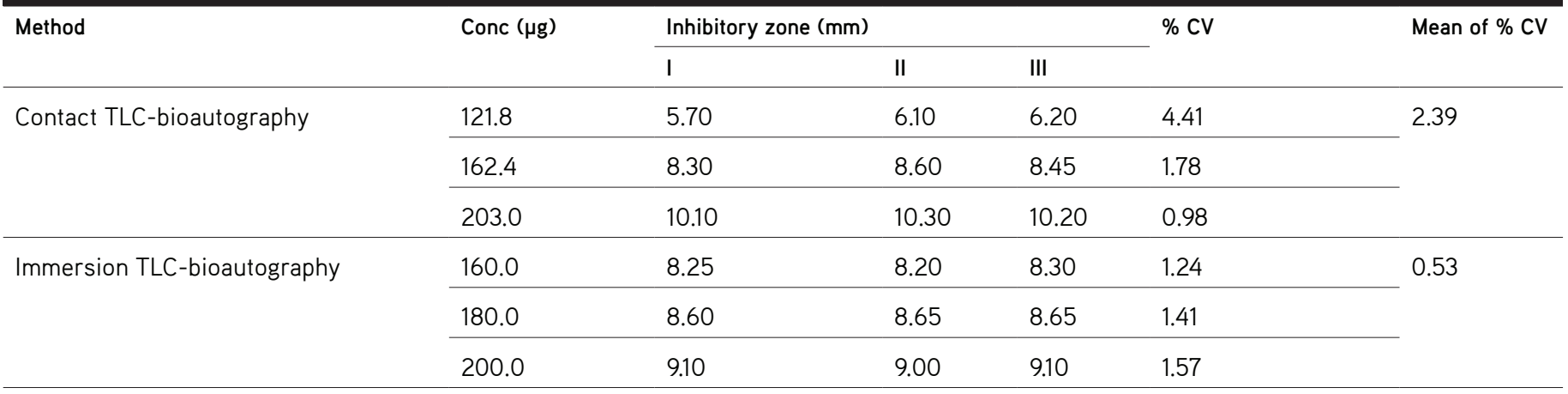

$\%$ CV: Percent coefficient of variation, TLC: Thin layer chromatography

\section{ACKNOWLEDGEMENT}

The current research was funded by Directorate General of the Ministry of Research and Technology.

Conflicts of interest: No conflict of interest was declared by the authors. The authors alone are responsible for the content and writing of this article.

\section{REFERENCES}

1. Serrano PH. Responsible use of antibiotics in aquaculture ( $1{ }^{\text {st }}$ ed). Rome; FAO;2005:469.

2. Irwandaru D, Ajie W. Peningkatan Daya Saing Produk Lokal Dalam Upaya Standardisasi Memasuki Pasar Global (Standardisasi Mutu dan Kualitas Udang Windu). UG Journal. 2013;6:9-15.

3. Minister of Marine and Fisheries of The Republic of Indonesia. Control of Fish Drug Residues, Chemicals, and Contaminants in Consumption of Fish Cultivation Activities. Regulation of The Minister of Marine and Fisheries of The Republic of Indonesia. 2015;1:1-19. Available from: https:// www.google.com/url?sa=t\&source=web\&rct=j\&url=http://jdih.kkp.go.id/ peraturan/per-02-men-2007.pdf\&ved=2ahUKEwiHz-Sa7uvpAhVwZhUI Hfe3ANOQFjAAegQIARAC\&usg=AOvVaw3U-T8wCcsjXKbKzv5sqinU

4. United States of Pharmacopeia. Aminoglycosides. Drugs for Animal Use. Veterinary-Systemic. United States of Pharmacopeia Convention. 2007:1-30. Available from: https://www.google.com/ url?sa=t\&source=web\&rct=j\&url=https://cdn.ymaws.com/www. aavpt.org/resource/resmgr/imported/aminoglycosides.pdf\&ved =2ahUKEwjLtYXb7evpAhXdTRUIHTBmASEQFjAAegQIBBAB\&usg= AOvVaw2vLeMHyRoysJa ZGjZDNmRa

5. Holmström K, Gräslund S, Wahlström A, Poungshompoo S, Bengtsson BE, Kautsky N. Antibiotic use in shrimp farming and implications for environmental impacts and human health. J Food Sci Technol. 2003;38:255-266.
6. World Health Organization. Dihydrostreptomycin/Sterptomyicin. In: Maximum Residue Limits (MRLs) and Risk Management Recommendations (RMRs) for Residues of Veterinary Drugs in Foods, 2nd ed. USA: FAO: 2018;2:18.

7. Okocha RC, Olatoye IO, Adedeji OB. Food safety impacts of antimicrobial use and their residues in aquaculture. Public Health Rev. 2018;39:21.

8. Choma IM, Grzelak EM. Bioautography detection in thin-layer chromatography. J Chromatogr A. 2011;1218:2684-2691.

9. Dewanjee S, Gangopadhyay M, Bhattacharya N, Khanra R, Dua TK. Bioautography and its scope in the field of natural product chemistry. $J$ Pharm Anal. 2015;5:75-84.

10. Mufida FA. Perbandingan Metode KLT-Densitometri Dan Bioautografi Untuk Penetapan Kadar Kanamisin Dalam Matriks Udang. Final Report. 2010.

11. Anggraeni FY. Perbandingan Validasi Metode KLT-Densitometri dan KLTBioautografi untuk Penetapan Kadar Oksitetrasiklin dalam Udang. Final Report. 2010.

12. Jahanbakhshi A. Determination some engineering properties of snake melon (Cucumis melo var. flexuosus) fruit Agric Eng Int CIGR J. 2018;20:171-176.

13. Astuti A. Validasi Metode Bioautografi untuk Determinasi Streptomisin Sulfat. Final Report. 2006.

14. Anonim.Penetapan SusutPengeringan In:Farmakope Indonesia V. Jakarta: Departemen Kese hatan RI. 2014:1043-1044. Avail able from: https://www. google.com/url?sa=t\&source=web\&rct=j\&url=https://www.academia. edu/35210175/Farmakope_Indonesia_V.pdf\&ved=2ahUKEwjQjvi38 OvpAhWDUhUIHYmKBpEQFjADegQIARAB\&usg=AOvVaw0qdSY3u gzGReN_CB2ImOeO

15. Kusumaningtyas E, Astuti E, Darmono D. Sensitivitas metode bioautografi kontak dan agar overlay dalam penentuan senyawa antikapang. J IImu Kefarmasian Indonesia. 2008;6:75-79. 